OPEN ACCESS

Edited by: Bimal Malhotra, Pfizer, United States

Reviewed by: Sandra Sigala,

University of Brescia, Italy Mohamed Fizur Nagoor Meeran, United Arab Emirates University,

United Arab Emirates

*Correspondence:

Yonggang Gao

gyg3177@163.com

Shijiang Sun

sunshijiang6909@163.com

LiChu

chuli0614@126.com

Specialty section:

This article was submitted to Cardiovascular and Smooth

Muscle Pharmacology,

a section of the journal

Frontiers in Pharmacology

Received: 27 April 2019 Accepted: 30 April 2020

Published: 15 May 2020

Citation:

Ma D, Zheng B, Du H, Han X, Zhang $X$,

Zhang J, Gao Y, Sun S and Chu L (2020) The Mechanism Underlying the

Protective Effects of Tannic Acid Against Isoproterenol-Induced Myocardial Fibrosis in Mice.

Front. Pharmacol. 11:716. doi: 10.3389/fphar.2020.00716

\section{The Mechanism Underlying the Protective Effects of Tannic Acid Against Isoproterenol-Induced Myocardial Fibrosis in Mice}

\author{
Donglai Ma ${ }^{1,2,3}$, Bin Zheng ${ }^{1}$, Huiru $\mathrm{Du}^{4}$, Xue Han ${ }^{1}$, Xuan Zhang ${ }^{5}$, Jianping Zhang ${ }^{5}$, \\ Yonggang $\mathrm{GaO}^{5 *}$, Shijiang Sun ${ }^{6 *}$ and Li Chu ${ }^{1,3^{*}}$ \\ ${ }^{1}$ School of Pharmacy, Hebei University of Chinese Medicine, Shijiazhuang, China, ${ }^{2}$ Collaborative Innovation Center of \\ Integrative Reproductive Disorders, Hebei University of Chinese Medicine, Shijiazhuang, China, ${ }^{3}$ Hebei Key Laboratory of \\ Integrative Medicine on Liver-Kidney Patterns Hebei University of Chinese Medicine, Shijiazhuang, China, ${ }^{4}$ Department of \\ Pharmaceutical Engineering, Hebei Chemical and Pharmaceutical College, Shijiazhuang, China, ${ }^{5}$ School of Basic Medicine, \\ Hebei University of Chinese Medicine, Shijiazhuang, China, ${ }^{6}$ Hebei Province Hospital of Chinese Medicine, Affiliated Hospital, \\ Hebei University of Chinese Medicine, Shijiazhuang, China
}

Tannic acid (TA) belongs to a class of complex water-soluble polyphenolic derivatives that show anticarcinogenic, antiinflammatory, antioxidant, and scavenging activities. Here, we investigate the protective effects of TA against isoproterenol (ISO)-induced myocardial fibrosis (MF) in mice. Mice received TA and ISO dosing and were sacrificed $48 \mathrm{~h}$ later. The activities of creatine kinase (CK), creatine kinase-MB (CK-MB), lactate dehydrogenase $(\mathrm{LDH})$, and mitochondria enzymes were measured. Cardiac histopathology was done using H\&E, Sirius red, and Masson's Trichrome staining. Immunohistochemical staining was applied to indicate changes in B-cell lymphoma-2 (Bcl-2), Bcl-2-associated X protein (Bax), and basic fibroblast growth factor (bFGF) protein expressions in cardiac tissue. RTPCR was used to measure the expression of atrial and brain natriuretic peptides (ANP and $\mathrm{BNP}$, respectively), $\mathrm{c}$-fos, and $\mathrm{c}$-jun. Western blotting was used to measure the expression of nuclear factor- $\mathrm{KB}(\mathrm{NF}-\mathrm{\kappa B}) \mathrm{p} 65$, phosphorylated NF- $\mathrm{kB}$ p65), toll-like receptor 4 (TLR4), p38, phosphorylated p38, Bax, Bcl-2, and caspase-3. Compared to the ISO group, the TA group had reduced levels of TLR4, p38, p-p38, NF- $\mathrm{BB}$ (p65), p-NF$\kappa B$ (p-p65), caspase-3, Bax, and $\mathrm{Bcl}-2$, as well as CK, CK-MB, and LDH. These results indicate that TA protects against ISO-induced MF, possibly through its ability to suppress the TLR4-mediated NF- $\mathrm{KB}$ signaling pathway.

Keywords: tannic acid, cardioprotection, isoproterenol, toll-like receptor 4, nuclear factor $\mathrm{kB}$, myocardial fibrosis

\section{INTRODUCTION}

Despite increasing mean lifespan and living standards, cardiovascular disease (CVD) remains a major cause of death (Oka et al., 2014). Myocardial fibrosis (MF) is an important pathological change that eventually leads to heart failure. MF typically results from the continuous progression of CVD (e.g., myocardial infarction and hypertension) (Wu et al., 2009; Duygu et al., 2013). MF is a key pathological feature of 
myocardial remodeling and an important cause of CVD formation. MF manifests mainly as excessive collagen fiber deposition in cardiac muscle tissue, a significant increase in collagen content, an imbalance in the proportion of collagen types (increased proportions of I/III), and disorganized collagen arrangements. However, the mechanism underlying MF remains unclear (Elliott et al., 2000).

Excessive activation of the $\beta$-adrenergic receptor is an important factor contributing to MF (Ayala et al., 2012). Excessive activation of the $\beta$-adrenergic receptoris characterized by the normal activity of important myocardial neurohumoral factors, but long-term $\beta$ receptor activation can lead to myocardial interstitial cell prolife proportion, fibrous tissue hyperplasia, and excess amounts of collagen and cellulose (Boluyt et al., 1995). It has been shown that continuous use of the $\beta$-adrenergic receptor agonist isoproterenol (ISO) can induce MF in rats (Borges et al., 2003; Zhang et al., 2016a; Zhang et al., 2016b).

Toll-like receptors (TLRs) provide a link between the immune system and the development of CVD (Avlas et al., 2011). Among TLRs, TLR4 is associated with human CVDs and is an important receptor for mediating myocardial inflammatory signals (Yin et al., 2015). Activation of TLR4 can increase p38 MAPK and nuclear factor $\mathrm{kB}$ $(\mathrm{NF}-\mathrm{kB})(\mathrm{p} 65)$ representations, which in turn lead to the expression of inflammatory factors. NF- $\kappa B$ (p65) activities also play a role in the regulation of TLR4 (Freund et al., 2005; Eguchi and Manabe, 2014).
Tannic acid (TA; Figure 1) is a class of more complex plant polyphenol derivatives (Haslam et al., 1989). It is abundant in cereals, fruits, herbs, tea, and red wine (Henis et al., 1964; Thiansilakul et al., 2012). TA's chemical structure contains glucose linked to a 3-5 gallic acid via an ester bond (Yugarani et al., 1993). Previous studies have suggested that TA possessesanti-lipogenic, anticarcinogenic, antiinflammatory, antioxidant, and scavenging activities (Gali et al., 1992; Chu et al., 2016). TA has some potent pharmacological effects, including myocardial protection (Hu et al., 2015; Zhang et al., 2017a; Zhang et al., 2017b), a decrease in L-type $\mathrm{Ca}^{2+}$ currents in isolated mice ventricular myocytes (Zhu et al., 2016), and a vasodilatory effect via activation of $\mathrm{K}^{+}$channels expressed in HEK293 cells (Chu et al., 2015; Zhang et al., 2016a). However, the relevance of the protective results of TA on chronic MF is not well-defined.

To investigate whether TA has inhibitory effects on ISOinduced MF, we studied inflammation and apoptosis-associated

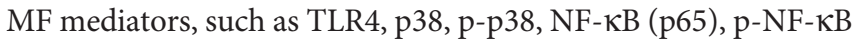
(p65), B-cell lymphoma-2 (Bcl-2), and Bcl-2-associated protein (Bax). It has been reported that the $\beta$-adrenergic receptor blocker of propranolol (Pro) provides significant protection against ISOinduced MF (Zheng et al., 2007). Therefore, Pro was applied as a positive control drug.<smiles>O=C(OC[C@H]1O[C@@H](OC(=O)c2cc(OC(=O)c3cc(O)c(O)c(O)c3)cc(C(=O)Oc3cc(C(=O)Oc4cc(O)c(O)c(O)c4)cc(C(=O)Oc4cc(O)c(O)c(O)c4O)c3)c2)[C@H](O)[C@@H](OC(=O)c2cc(O)c(O)c(O)c2)[C@@H]1OC(=O)c1cc(O)c(O)c(OC(=O)c2cc(O)c(O)c(O)c2)c1)c1cc(O)c(O)c(OC(=O)c2cc(O)c(O)c(O)c2)c1</smiles>

FIGURE 1 | Tannic acid (TA) structure. 


\section{MATERIALS AND METHODS}

\section{Animals}

Male Kunming mice (KM, 20-22 g) were purchased from Hebei Medical University (Shijiazhuang, China). Animals were free to consume food and water in a standard laboratory environment $\left(12 / 12 \mathrm{~h}\right.$ day and night cycle, $25^{\circ} \mathrm{C} \pm 1^{\circ} \mathrm{C}, 55 \% \pm 10 \%$ humidity) and subcage-adapted for 7 days. All experiments conformed to the Guide for the Care and Use of Laboratory Animals published by the US National Institutes of Health (NIH Publication, 8th Edition, 2011). This study was carried out following the recommendations of the Declaration of Helsinki. The protocol was approved by the Hebei University of Chinese Medicine Committee on Animal Care.

\section{Reagents}

TA was purchased from Sigma-Aldrich (Shanghai, China) (Figure 1). ISO was obtained from Amylet Scientific (Michigan, USA). Propranolol was purchased from Afar Sally Chemical Co. (Tianjin, China).

\section{Preexperiment}

Methods from other literature reports, including ISO dose, modeling cycle, and safety issues, were used to investigate the mouse MF model. Twelve Kun Ming (KM) mice were administered subcutaneously with ISO at $10 \mathrm{mg} / \mathrm{kg} /$ day and mice were sacrificed 14 days after continuous administration. We detected obvious pathological MF changes that were consistent with those from other reports (Wu et al., 2009). The mouse MF model was also shown to be successful. The modeling method and ISO dose were shown to be safe and reliable in mice.

\section{Experimental Design}

The animals were randomly (random number table method) divided into groups. Fifty healthy KM mice were randomized into five groups: (1) control group (CONT, $\mathrm{n}=10$ ), subcutaneously administered normal saline $(10 \mathrm{mg} / \mathrm{kg} / \mathrm{day})$ subcutaneous and intraperitoneal; (2) ISO group $(\mathrm{n}=10)$, subcutaneously administered ISO (10 mg/kg/day) plus normal saline $(10 \mathrm{mg} / \mathrm{kg} /$ day); (3) Pro group $(\mathrm{n}=10)$, subcutaneously administered ISO (10 $\mathrm{mg} / \mathrm{kg} /$ day) plus (Pro $40 \mathrm{mg} / \mathrm{kg} /$ day); (4) low-dose TA group (LTA, $n=10)$, subcutaneously administered ISO (10 mg/kg/day) plus TA (20 mg/kg/day); and (5) high-dose TA group (H-TA, $\mathrm{n}=10$ ), subcutaneously administered ISO (10 mg/kg/day) plus TA (40 mg/ $\mathrm{kg} /$ day).

Body weight gains and feed efficiencies were calculated. All mice were sacrificed after 14 days. Blood was gathered retroorbitally at room temperature, then centrifuged at $3000 \mathrm{rpm}$ for $30 \mathrm{~min}$ and preserved at $-20^{\circ} \mathrm{C}$. The hearts were quickly separated, weighed, and preserved at $-80^{\circ} \mathrm{C}$ or fixed with $10 \%$ paraformaldehyde.

\section{ELISA Assay}

The isolated serum sample was used for the diagnosis of labeled enzymes. Total serum CK, CK-MB, and $\mathrm{LDH}$ were detected using the velocity method at $37^{\circ} \mathrm{C}$ using the $\mathrm{CK}, \mathrm{CK}-\mathrm{MB}$, and
LDH kit (Jiancheng Biological Engineering Institute, China), which is based on an enzyme-coupled reaction.

\section{Detection of Mitochondrial Enzyme Activities}

A well-ground $10 \%$ homogenate of heart tissue was centrifuged at 3,000 rev/min for $10-15 \mathrm{~min}$ at low temperature to prepare a supernatant for the determination of mitochondrial enzyme activities. The supernatant at 100,000 g were centrifuged for 1 $\mathrm{h}$ and the precipitate is mitochondria. The separated mitochondria were made into a suspension with $4^{\circ} \mathrm{C}$ homogenized medium, and the mitochondria were broken three to five times in an ice-water mixture using an ultrasonic generator $400 \mathrm{~mA}, 5 \mathrm{~s} /$ times, and a gap of $10 \mathrm{~s}$. After the coomassie brilliant blue method was used to determine the protein content, aliquots were stored in a refrigerator at $-80^{\circ} \mathrm{C}$ for future use. $\mathrm{Na}^{+}, \mathrm{K}^{+}$-ATPase and $\mathrm{Ca}^{2+}, \mathrm{Mg}^{2+}$-ATPase activities of myocardial mitochondria were measured according to the operating instructions of the ATPase kit (Jiancheng Biological Engineering Institute, China).

\section{H\&E, Sirius Red, and Masson's Trichromestaining}

Mice hearts fixed in 4\% paraformaldehyde solution were taken from the same location. The hearts were then paraffin-embedded after routine treatment and sliced into $4-\mu \mathrm{m}$ sections. The sections were stained with H\&E, Sirius red, and Masson's trichrome staining. After staining was complete, collagen fibers were surveyed under a light microscope. According to the semiquantitative scoring system for MF, the degree of MF in each group was scored. A higher score indicates a more severe degree of fibrosis.

\section{Immunohistochemistry}

The paraffin specimens were sectioned for immunohistochemistry. The sections were boiled in $10 \mathrm{mM}$ sodium citrate buffer for $20 \mathrm{~min}$, then cooled to room temperature. Following antigen retrieval, sections were peroxidase blocked in $3 \% \mathrm{H}_{2} \mathrm{O}_{2}$ for $10 \mathrm{~min}$ and blocked with $10 \%$ normal goat serum at $37^{\circ} \mathrm{C}$ for $15 \mathrm{~min}$. After incubation with the primary antibody, the slides were incubated with diluted rabbit polyclonal antibodies to Bax (AB32503, Abcam, Cambridge, UK; 1:65), Bcl-2 (AB32124, Abcam, Cambridge, UK; 1:70), or bFGF (AB4222, Abcam, Cambridge, UK; $1: 60$ ) at $4^{\circ} \mathrm{C}$ overnight. The streptavidin/peroxidase complex was applied to slide sections and incubated at $37^{\circ} \mathrm{C}$ for $15 \mathrm{~min}$ and $3,3^{\prime}-$ diaminobenzidine hydrochloride was added to the tissue portions. The sections were counterstained with hematoxylin and sealed with neutral gum. Five pictures $(\times 400)$ per heart were recorded randomly through a digital microscope (Olympus) and quantified with LAS 4.2 software.

\section{Reverse Transcription PCR}

The Trizol reagent was used to extract total myocardial RNA. For the total RNA, the absorbance was measured at 260/280 nm using a microplate reader. Total RNA (2 $\mu \mathrm{g})$ was reverse transcribed into cDNA using an reverse transcription PCR 
(RT-PCR) synthesis kit (TaKaRa Bio Inc., Dalian, China). The sequences of primers were as follows: ANP (sense 5'GGCTTCTTCCTCGTCTTGG-3'; antisense $5^{\prime}$ ATCTGTGTTGGACACCGCA-3'); BNP (sense 5'CGGTCTCAAGGCAGCAC-3'; antisense $5^{\prime}$ GTTACAGCCCAAACGACT-3'); c-fos (sense 5' ACGGACTCCCCACCCAG-3'; antisense $5^{\prime}$ CGTTCCCTTCGGATTCT-3'); c-jun (sense 5' GCCCCTGTCCCCTATCG-3'; antisense $5^{\prime}$ TCCAGCTTCCTTTTCCG-3'); and $\beta$-actin (sense $5^{\prime}$ GAGAGGGAAATCGTGCGTGACA-3'; antisense 5' ACCCAAGAAGGAAGGCTGGAAA-3') served as the internal control.

The RT parameters were: (1) $30^{\circ} \mathrm{C}$ for $10 \mathrm{~min}$; (2) $42^{\circ} \mathrm{C}$ for 30 $\min$; (3) $5^{\circ} \mathrm{C}$ for $5 \mathrm{~min}$. RT-PCR was done according to the manufacturer's instructions. The reaction consisted of: (1) $94^{\circ} \mathrm{C}$ for $5 \mathrm{~min}$; (2) $94^{\circ} \mathrm{C}$ for $30 \mathrm{~s}$; (3) $72^{\circ} \mathrm{C}$ for $10 \mathrm{~min} ; 35$ cycles. The PCR products were analyzed by $1.5 \%(\mathrm{w} / \mathrm{v})$ agarose gel electrophoresis. The GL2200PROgel imaging system was applied to scan the gray scale of the specific PCR products amplified by each sample. The relative transcript levels of ANP, BNP, c-fos, and c-jun were normalized to $\beta$-actin.

\section{Western Blotting}

The RIPA lysate ( $1 \mathrm{mmol} / \mathrm{L}$ PMSF) was added to each group's hearts in an ice bath with stirring for $0.5 \mathrm{~h}$. The supernatant was centrifuged for $0.5 \mathrm{~h}$, and protein concentrations were determined using the bicinchoninic acid (BCA) method (BCA kit, SangonBiotech, Shanghai, China). The proteins were separated on SDS-PAGE and transferred to nitrocellulose membranes. The membranes were blocked with 5\% skim milk powder at $24^{\circ} \mathrm{C}$ for $2 \mathrm{~h}$ and then incubated with primary antibody rabbit anti-rat TLR4 (1:1,000 dilution), p38 (1:1,000 dilution), p-p38 (1:500 dilution), NF- $\kappa B$ (p65) (1:3,000 dilution), p-NF- $\kappa B$ (p65) (1:1,000 dilution), Bax (1:1,000 dilution), Bcl-2 (1:1,000 dilution), caspase-3 (1:1,000 dilution), and mouse antibody $\beta$-actin at a $1: 1,000$ dilution at $4^{\circ} \mathrm{C}$ for $10 \mathrm{~h}$. After rewarming, the membrane was blocked with a secondary antibody for $90 \mathrm{~min}$. The membrane was washed, subjected to chemiluminescence, developed, and fixed. Images were acquired using a Fluor Chem Q multifunctional imaging and quantitative analysis system. With $\beta$-actin as an internal reference, the proportion of absorbance value between the target protein and reference absorbance value represented the relative expression content of the target protein.

\section{Statistical Methods}

The data are expressed as the mean \pm standard error of the mean, and the differences between the groups were quantified by analysis of variance (ANOVA) or Dunnett's T-test. P-values $<0.05$ were considered to be statistically significant. All statistical analyses were done using the Statistical Packagefor Social Science (SPSS, Chicago, IL), Version 24.0.

\section{RESULTS}

\section{Effects of TA on Levels of CK, CK-MB, and LDH}

The CK, CK-MB, and $\mathrm{LDH}$ levels in serum were tested in accordance with the kit method. In Figure 2, ISO-induced significant increases in $\mathrm{CK}, \mathrm{CK}-\mathrm{MB}$, and $\mathrm{LDH}$ compared with CONT group. Compared with the ISO group, CK, CK-MB, and $\mathrm{LDH}$ serum levels in per group had significantly decreased $(\mathrm{P}<0.05$ and $\mathrm{P}<0.01)$. In MF mice, $\mathrm{H}$-TA group was better able to lower serum CK, CK-MB, and LDH levels than L-TA group.

\section{Effects of TA on Mitochondrial Enzyme Activities}

Mitochondrial enzyme activities in each group is shown in Figure 3. ISO-induced significant reduces $\mathrm{Na}^{+}, \mathrm{K}^{+}$-ATPase and $\mathrm{Ca}^{2+}, \mathrm{Mg}^{2+}$-ATPase activities of myocardial mitochondria compared with CONT group. Compared with the ISO group, $\mathrm{Na}^{+}, \mathrm{K}^{+}$-ATPase and $\mathrm{Ca}^{2+}, \mathrm{Mg}^{2+}$-ATPase activities in per group had significantly increased $(\mathrm{P}<0.05$ and $\mathrm{P}<0.01)$. In $\mathrm{MF}$ mice, $\mathrm{H}-$ TA group was better able to higher $\mathrm{Na}^{+}, \mathrm{K}^{+}$-ATPase and $\mathrm{Ca}^{2+}$, $\mathrm{Mg}^{2+}$-ATPase activities than L-TA group.

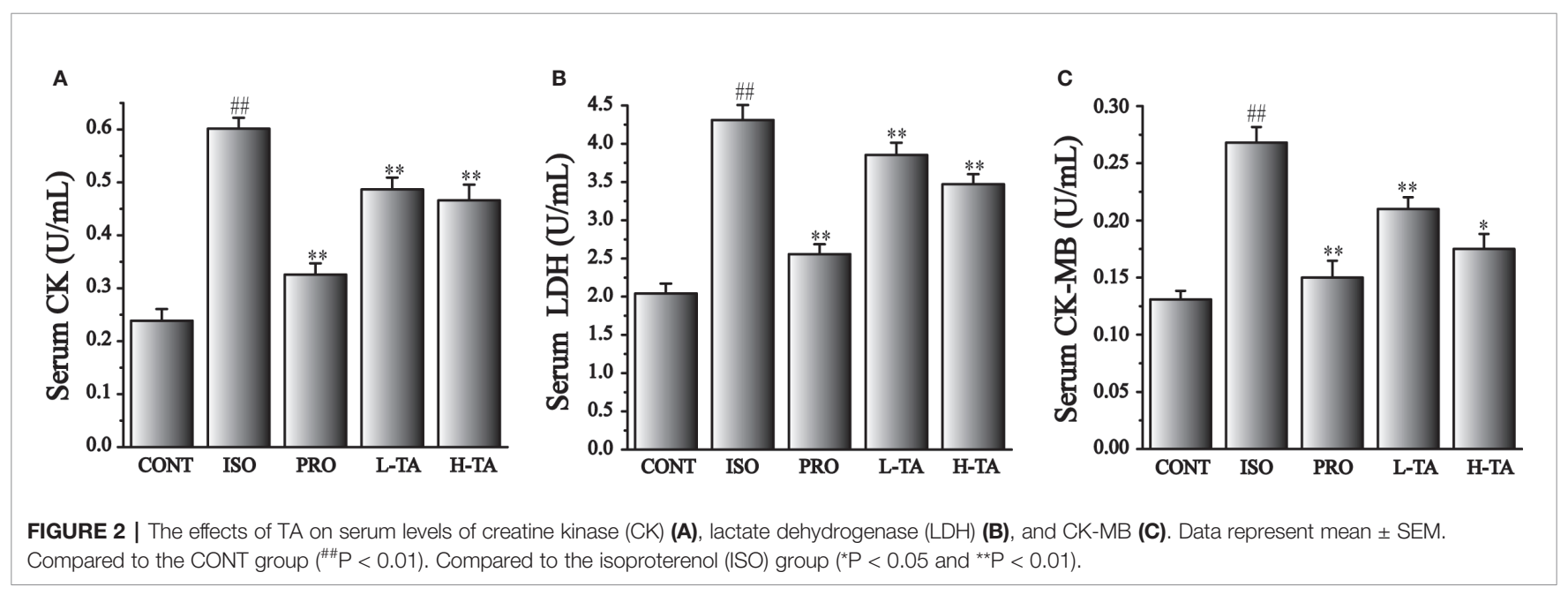



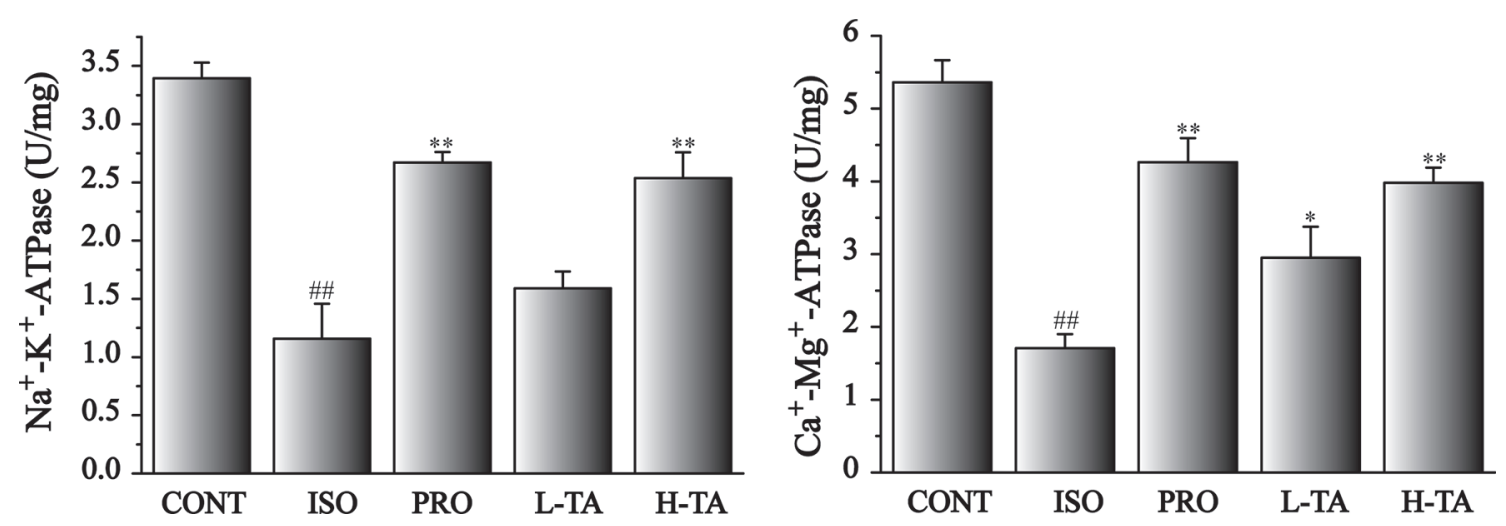

FIGURE 3 | The effects of tannic acid (TA) on mitochondrial enzyme activities. Data represent mean \pm SEM. Compared to the CONT group (\#\# $\mathrm{P}<0.01)$. Compared to the isoproterenol (ISO) group ( ${ }^{*} P<0.05$ and $\left.{ }^{* *} P<0.01\right)$.

\section{Myocardium Pathology H\&E Staining}

$\mathrm{H} \& \mathrm{E}$ staining of myocardial tissue in each group is shown in Figure 4. The proportion of the positive area of collagen fibers was calculated using Image-Pro Plus 5.0. In the CONT group, MF was arranged in neat rows showing myocardial cells without atrophy or hypertrophy, indicating normal myocardial structure. The fibers in the ISO group of MF were disrupted and disordered, and the myocardial interstitial collagen fibers increased dramatically $(\mathrm{P}<0.01)$. Contrasted with the ISO group, the TA groups had dramatically decreased myocardial interstitial collagen fibers $(\mathrm{P}<0.01)$, especially in the $\mathrm{H}$-TA group in which myocardial interstitial fibers occasionally showed a small amount of collagen fibrosis and inflammatory cell infilt proportion.
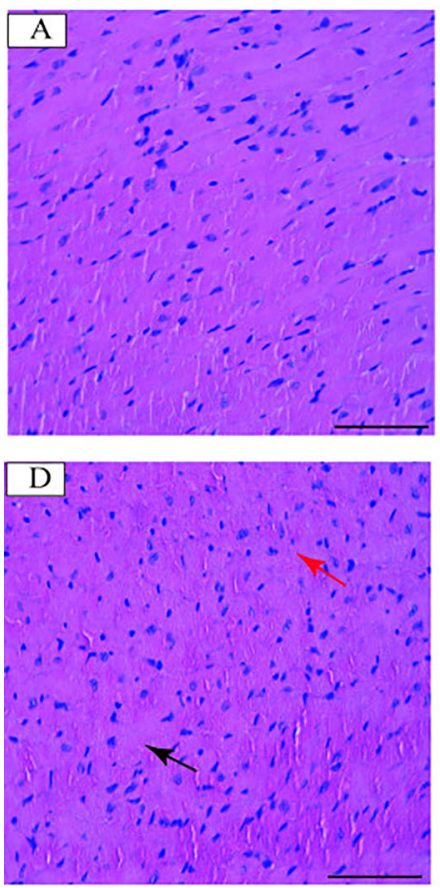
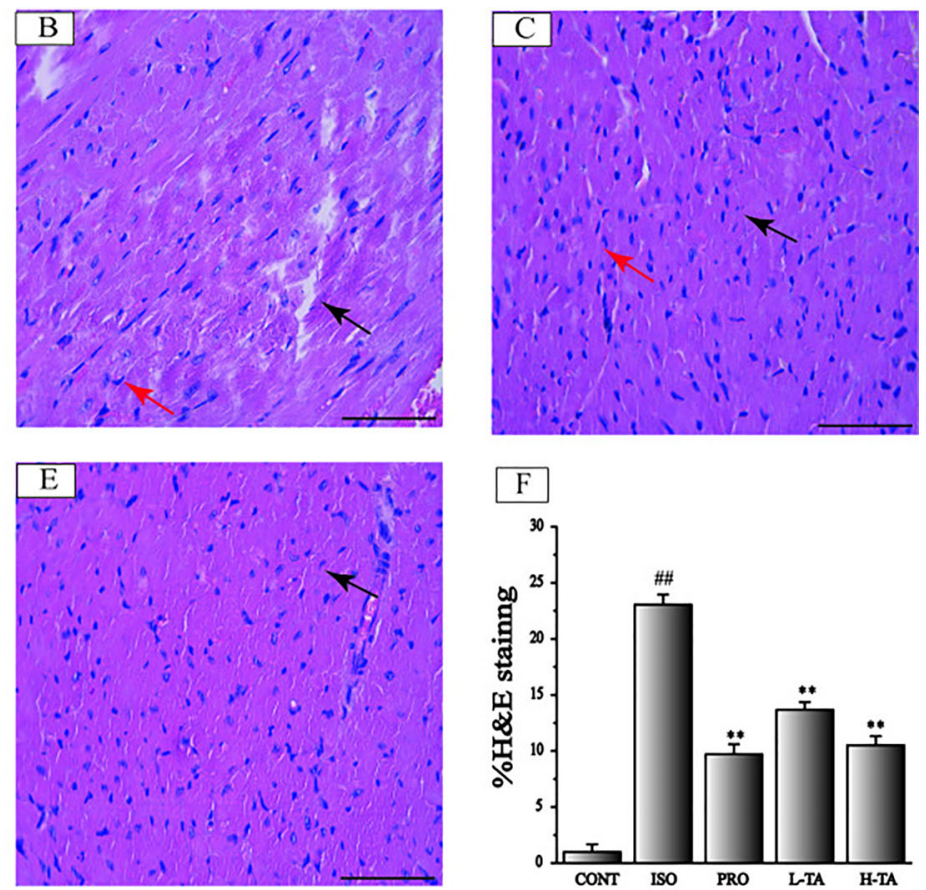

FIGURE 4 | The effects of tannic acid (TA) on cardiac fibrosis as surveyed by H\&E staining. The staining is shown for the CONT (A), isoproterenol (ISO) (B), PRO (C), low-dose TA (L-TA) (D), and high-dose TA (H-TA) (E) groups (H\&E, 400x; bar $50 \mu \mathrm{m}$ ). Pay attention note the cardiomyocytes' derangement distribution (arrows) as revealed with H\&E staining. (F) Quantification of the H\&E staining expressed as the proportion of the area positive for collagen fibers. Data represent mean \pm SEM. Compared to the CONT group $(" \# P<0.01)$. Compared to ISO group $\left({ }^{* *} P<0.01\right)$. 


\section{Sirius Red Staining}

Sirius red staining has been reported as the most appropriate stain in the evidentiation of MF (Cowling et al., 2019). Sirius red stained heart sections from the control group were observed under the microscope (Figure 5). Progressive interstitial fibrosis was observed in the ISO group. Versus the ISO group however, TA treatment significantly attenuated MF. Furthermore, myonecrosis lead to less edema, fewer inflammatory cells, and a decreased degree of myocardial structural disorder in the mesenchyme. As a positive control, the ISO+PRO also significantly relieved MF. The effect of TA was slightly weaker than PRO. In conclusion, TA could alleviate ISO-induced MF.

\section{Masson's Trichrome Staining}

Masson's trichrome staining of myocardial tissue is shown in Figure 6. For the CONT group mice, ventricular myocardial and myocardial interstitial collagen fibers can be seen, with a small amount of deposition. Collagen deposition in the ISO group was more pronounced. In the TA group, collagen deposition has been alleviated. The proportion of the surveyed area that was positive for collagen fibers was measured using Image-Pro Plus 5.0. Relative to the CONT group, the myocardial collagen fibers in the ISO group were dramatically increased. Compared to the ISO group, each TA group had dramatically decreased myocardial interstitial collagen fibers (Figure 6F).

\section{Results of TA on the Representation of Bax, Bcl-2, and $\mathrm{bFGF}$}

Immunohistochemistry was applied to detect Bax, Bcl-2, and bFGF expression levels in each group (Figure 7). The staining results were analyzed using Image-Pro Plus 5.0 software. We found that, compared to the CONT group, positive staining of Bax and bFGF and parenchymal areas increased dramatically in the ISO group $(\mathrm{P}<0.01)$, while $\mathrm{Bcl}-2$ expression decreased. Compared to the ISO part, each TA group had a significant decrease in Bax, Bcl-2, and bFGF expressions in the myocardium $(\mathrm{P}<0.01)$, while Bcl-2 expression increased.

\section{Effects of TA on the Expression of Bax/ $\mathrm{Bcl}-2$ and Caspase-3}

In the present study, the proportion of $\mathrm{Bax} / \mathrm{Bcl}-2$ and caspase- 3 proteins was analyzed by western blotting. As shown in Figure 8, when compared with the CONT group, the proportion of Bax/ $\mathrm{Bcl}-2$ and caspase- 3 proteins in the myocardial model of the ISO model group had increased dramatically $(\mathrm{P}<0.01)$, indicating that ISO could induce expression of $\mathrm{Bax} / \mathrm{Bcl}-2$ and caspase- 3 proteins in cardiomyocytes. Compared with the ISO group, the proportion of $\mathrm{Bax} / \mathrm{Bcl}-2$ and caspase- 3 in the myocardium of mice were dramatically lower than in the TA group $(\mathrm{P}<0.01)$, indicating that different TA doses can inhibit the expression of Bax/Bcl-2 and caspase-3 proteins in cardiomyocytes.

\section{Effects of TA on the Expression of ANP, BNP, c-fos, and c-jun}

The expression levels of ANP, BNP, c-fos, and c-jun mRNA were analyzed by RT-PCR (Figure 10). Compared to the CONT group, ANP and BNP expressions in the ISO group increased dramatically $(\mathrm{P}<0.01)$ (Figures 9A, B). When compared with the ISO group, mice myocardial ANP and BNP expressions dramatically decreased $(\mathrm{P}<0.01)$, indicating that TA could dramatically inhibit MF expression of ANP and BNP.

Compared with the CONT group, expressions of c-fos and cjun mRNA increased dramatically in the ISO group $(\mathrm{P}<0.01)$ (Figures 9C, D). Compared with the ISO group, $\mathrm{c}$-fos and $\mathrm{c}$-jun expressions in the myocardium dramatically decreased $(\mathrm{P}<$ $0.01)$, indicating that TA could dramatically inhibit $\mathrm{MF}$ expressing c-fos and c-jun mRNA.

\section{Effects of TA on the Expression of NF-kB (p65), p38, and TLR4}

In this study, NF- $\mathrm{BB}$ (p65), p38, and TLR4 proteins were analyzed by WB. As shown in Figure 10, when compared with the CONT group, the NF- $\mathrm{KB}$ (p65), p38, and TLR4 proteins in the myocardial model of the ISO group had increased dramatically $(\mathrm{P}<0.01)$, indicating that ISO could induce NF$\kappa \mathrm{B}$ (p65), p38, and TLR4 proteins in cardiomyocytes. Compared with the ISO group, the NF- $\kappa \mathrm{B}$ (p65), p38, and TLR4 proteins in the myocardium were dramatically decreased in the TA group ( $\mathrm{P}$ $<0.01$ ), indicating that different TA doses can dramatically inhibit NF- $\mathrm{KB}$ (p65), p38, and TLR4 proteins in cardiomyocytes.

\section{Effects of TA on the Expression of Phosphorylated NF-KB (p65) and p38}

As shown in Figure 11, when compared with the CONT group, the p-p65 and p-p38 proteins in the myocardial model of the ISO group had increased obviously $(\mathrm{P}<0.01)$, indicating that ISO could induce p-p65 and p-p38 proteins in cardiomyocytes. Compared with the ISO group, the $\mathrm{p}-\mathrm{p} 65$ and $\mathrm{p}$-p38 proteins
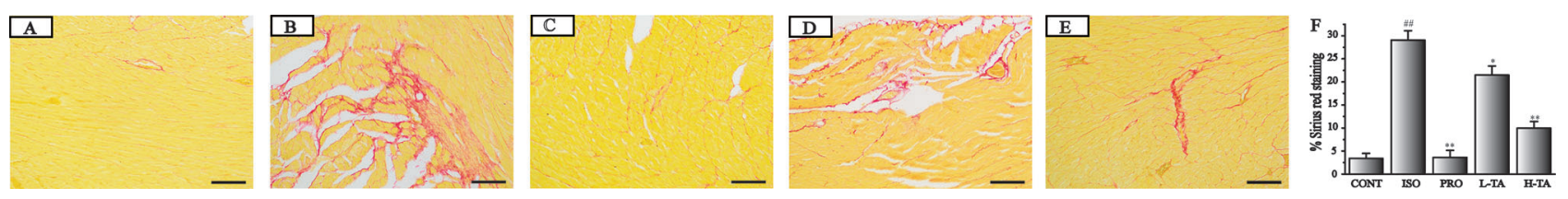

FIGURE 5 | The effects of tannic acid (TA) on cardiac fibrosis as surveyed by Sirius red staining. The staining is shown for the CONT (A), isoproterenol (ISO) (B), PRO (C), low-dose TA (L-TA) (D), and high-dose TA (H-TA) (E) groups (200x; bar $100 \mu \mathrm{m})$. (F) Quantification of Sirius red staining expressed as the proportion of the positive area for collagen fibers. Data represent mean \pm SEM. Compared to the CONT group $\left({ }^{\# \#} P<0.01\right)$. Compared to ISO group $\left({ }^{\star} P<0.05\right.$ and $\left.{ }^{\star \star} P<0.01\right)$. 

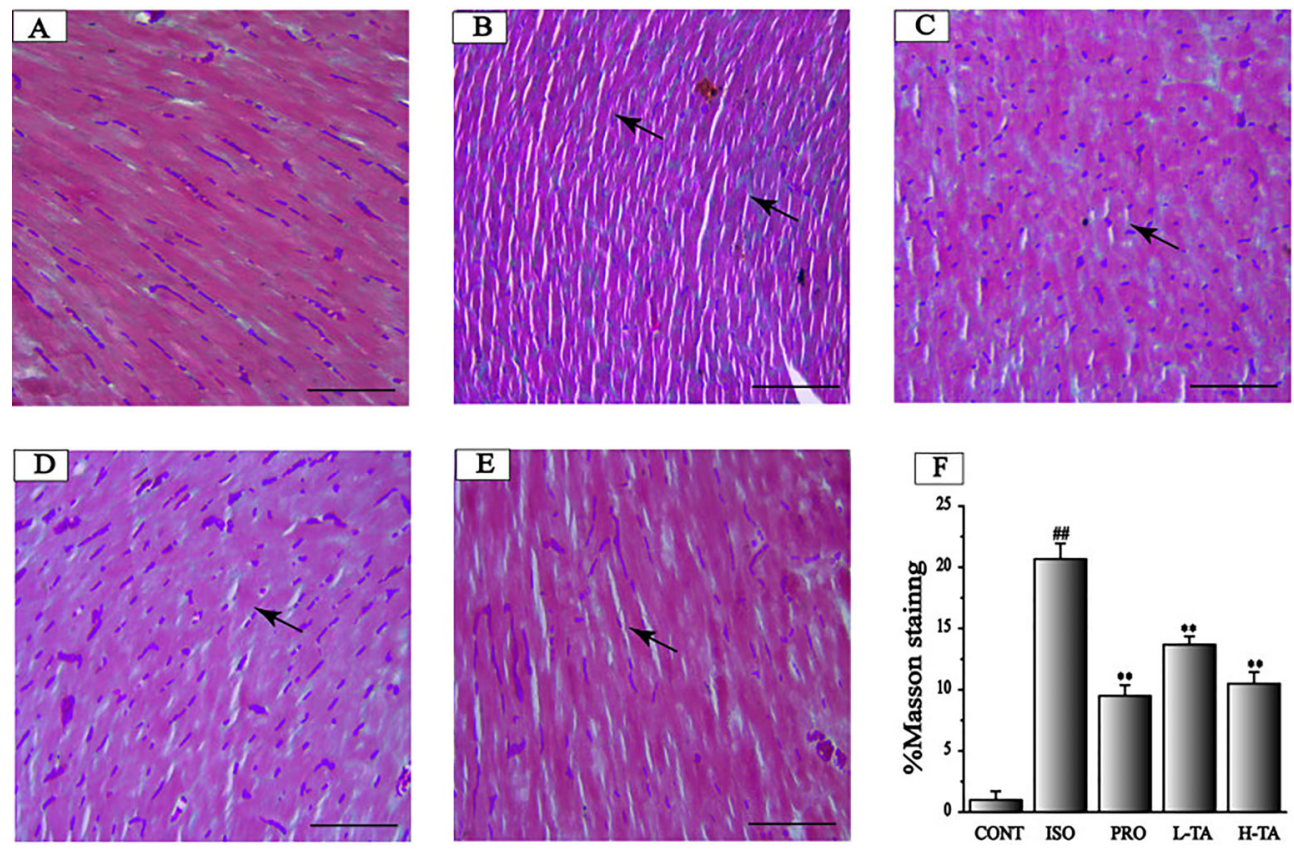

FIGURE 6 | The effects of tannic acid (TA) on myocardial fibrosis as surveyed by Masson's trichrome staining. The staining is shown for the CONT (A), isoproterenol (ISO) (B), PRO (C), low-dose TA (L-TA) (D), and high-dose TA (H-TA) (E) groups (Masson's trichrome staining, 400x; bar 50 um). (F) Quantification of Masson's trichrome staining expressed as the proportion of the positive area for collagen fibers. Data represent mean \pm SEM. Compared to the CONT group (\#\# $\mathrm{P}<0.01$ ). Compared to the ISO group $\left({ }^{\star *} \mathrm{P}<0.01\right)$.
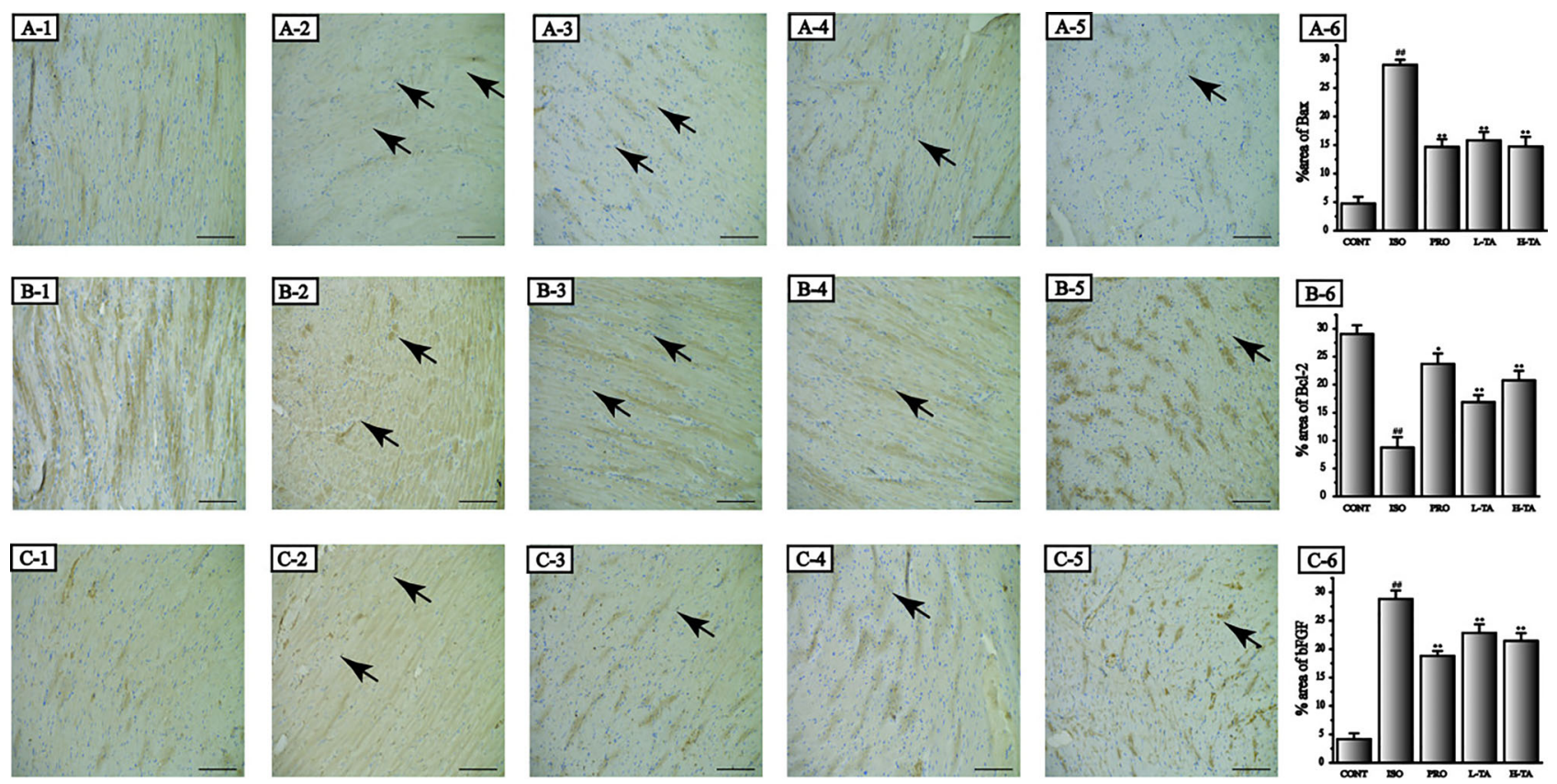

FIGURE 7 | The effects of tannic acid (TA) treatment on Bax, Bcl-2, and basic fibroblast growth factor (bFGF) expression in heart observed after immunohistochemical dispose of. The morphological locations and percent areas of Bax (A1-6), Bcl-2 (B1-6), and bFGF (C1-6) expressions are shown (immunohistochemical, 400x; bar $50 \mu \mathrm{m}$ ). Positive expressions of Bax, Bcl-2, and bFGF are indicated by arrows. Data represent the mean \pm SEM. Compared to the CONT group ( $\left.{ }^{\# \#} \mathrm{P}<0.01\right)$. Compared to the isoproterenol (ISO) group ( ${ }^{\star} \mathrm{P}<0.05$ and ${ }^{\star \star} \mathrm{P}<0.01$ ). 
A

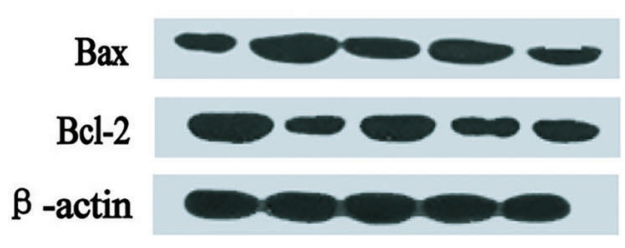

B

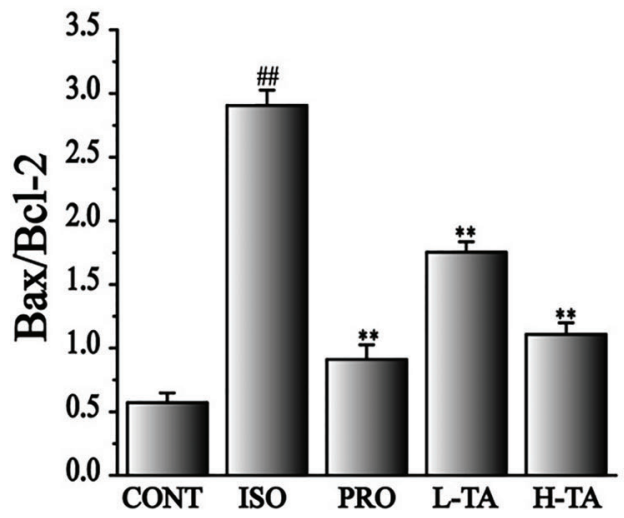

C

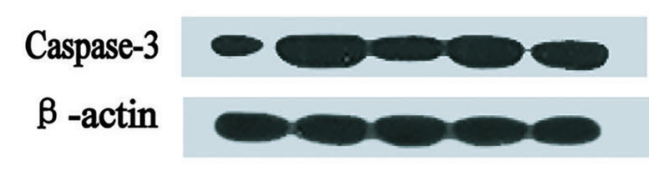

D

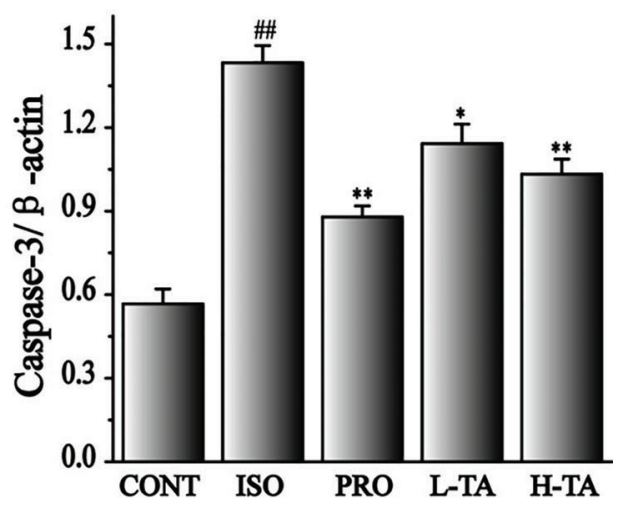

FIGURE 8 | The effects of tannic acid (TA) treatment on Bax, Bcl-2, and caspase-3 expressions as shown by Western blotting (WB) analysis. The band intensities of Bax/Bcl-2 (A, B) and caspase-3 (C, D) were analyzed by normalization to $\beta$-actin. Data represent mean \pm SEM. Compared to the CONT group (\#\# $<0.01)$.

Compared to the isoproterenol (ISO) group ( ${ }^{*} \mathrm{P}<0.05$ and $\left.{ }^{\star \star} \mathrm{P}<0.01\right)$.

in the myocardium were dramatically decreased in the TA group $(\mathrm{P}<0.01$ and $\mathrm{P}<0.05)$, indicating that different TA doses can dramatically inhibit phosphorylated NF- $\kappa B$ (p65) and p38 proteins in cardiomyocytes.

\section{DISCUSSION}

TA is commonly consumed in our daily life, such as in fruits, vegetables, wines, and tea. In the United States, on average, people consume $1 \mathrm{~g}$ of TA per day (Sanyal et al., 1997). Based on the formula proposed by Reagan-Shaw et al. (Reagan-Shaw et al., 2008), the doses (20 and $40 \mathrm{mg} / \mathrm{kg} /$ day) used in our experiment are close to people's typical daily consumption. In recent years, research on TA has shown that its inhalation attenuates intermittent hypoxia (Sato et al., 1999; Liang et al., 2009) or ischemia/reperfusion (Zhao et al., 2010). Our results provide new experimental evidence for the MF of action of TA and might help to expand clinical treatments for CVD.

The results of in vivo experiments showed that the CK, CK$\mathrm{MB}$, and $\mathrm{LDH}$ of mice decreased after 2 weeks of intraperitoneal TA injections as well as the activities of myocardial mitochondrial enzyme were significantly increased. Myocardial tissue H\&E, Sirius red, Masson's trichrome staining and immunohistochemical results also showed that TA could dramatically improve myocardial tissue morphology, alleviate myocardial mitochondrial damage, reduce collagen deposition, and reverse MF.
ISO can lead to apoptosis of cardiomyocytes. Apoptosis is an important reflection of harmful cell stimuli, which is of great significance for maintaining body homeostasis (O'Neill et al., 2009). TRL4 is a member of the signal transduction family (Shyu et al., 2010). Upon stimulation with exogenous LPS or endogenous ligands, TRL4 binds to the adapter protein MyD88 and is then processed through one of two ways (Li et al., 2004; Liu et al., 2015): (1) signaling through the pathway that includes the Rel family transcription factor NF- $\kappa B$ (p65); or (2) through the P38 MAPK and jnk pathway, which activates transcription factors, such as transcriptional activator II, and participates in signal transduction, transcription activation, and regulation of target gene expression.

NF- $\kappa B$ (p65) can be activated by a variety of cardiac hypertrophy stimulators (Gupta et al., 2008). Expressions of its downstream embryonic genes (e.g., ANP and BNP) increased dramatically, leading to hypertrophy of the myocardial cells (Zhang et al., 2003). It has been reported that continuous ISO injections can increase p-38 protein expression (Li et al., 2017; Zhang et al., 2016b), which is an important mediator of ISOinduced cardiac fibrosis in the pathogenesis. P38 MAPK is covered in intracellular formation transfer. P38 MAPK responds to a wide range of extracellular stimuli and mediates cell growth, development, differentiation, and death (Qiu et al., 2001). For example, Yin et al. applied the specific p38 MAPK inhibitor, SB203580, to study the regulatory results of p38 MAPK on Bcl-2 and found that the decrease in Bcl-2 expression slowed down, indicating that $\mathrm{p} 38 \mathrm{MAPK}$ is covered in the regulation of Bcl-2 (De Chiara et al., 2006; Yin et al., 2006). Feidantsis and 

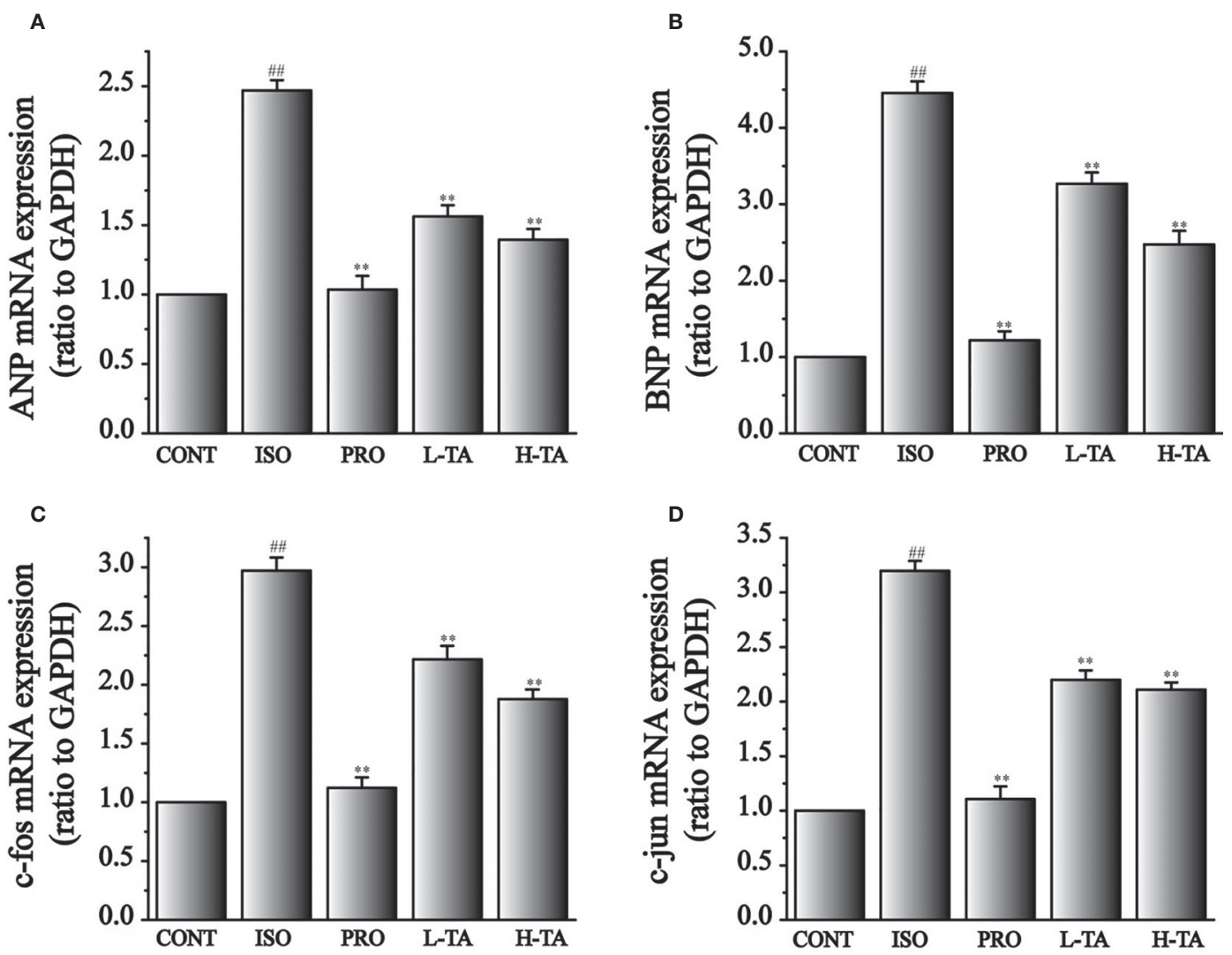

FIGURE 9 | The effects of tannic acid (TA) treatment on atrial natriuretic peptide (ANP) (A), brain natriuretic peptide (BNP) (B), c-fos (C), and c-jun (D) mRNA expressions, as shown by RT-PCR. Data represent mean \pm SEM. Compared to the CONT group (\#\# $<<0.01)$. Compared to the isoproterenol (ISO) group $\left({ }^{\star *} \mathrm{P}<0.01\right)$
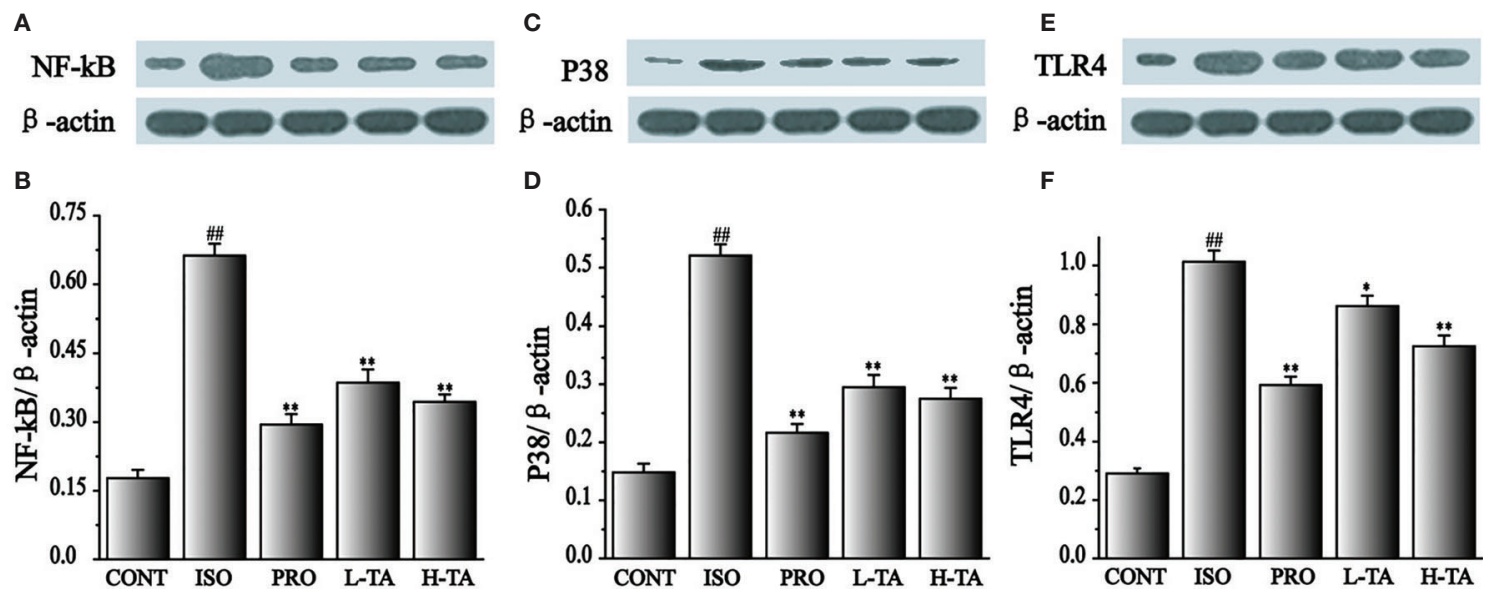

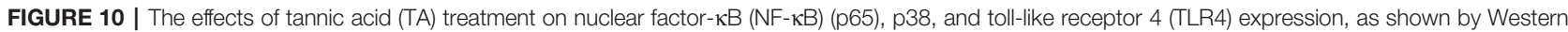
blotting (WB) analysis. Quantification of the NF- $\mathrm{KB}(\mathrm{p65}) \mathbf{( A , ~ B ) , ~ p 3 8 ~ ( C , ~ D ) ~ a n d ~ T L R 4 ~ ( E , ~ F ) ~ p r o t e i n ~ e x p r e s s i o n ~ n o r m a l i z a t i o n ~ t o ~ t h e ~} \beta$-actin. The mean \pm SEM are shown. Compared to the CONT group ( $\left.{ }^{\# \#} \mathrm{P}<0.01\right)$. Compared to the isoproterenol (ISO) group $\left({ }^{\star} \mathrm{P}<0.05\right.$ and $\left.{ }^{* \star} \mathrm{P}<0.01\right)$. 

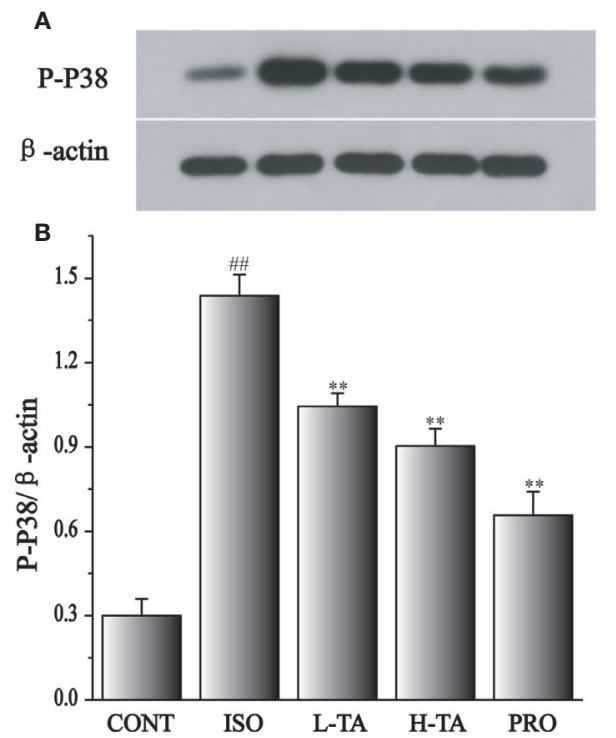

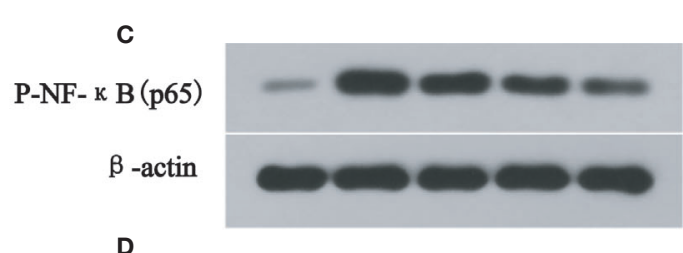

D

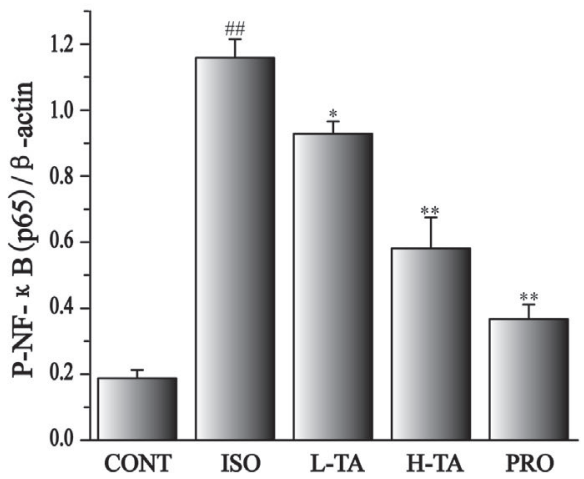

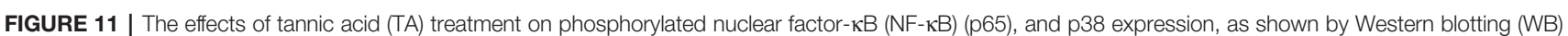
analysis. Quantification of the phosphorylated p38 (A, B), and NF-KB (p65) (C, D) protein expression normalization to the $\beta$-actin. The mean \pm SEM are shown. Compared to the CONT group ( $\left.{ }^{\# \# P}<0.01\right)$. Compared to the isoproterenol (ISO) group $\left({ }^{*} \mathrm{P}<0.05\right.$ and $\left.{ }^{\star \star} \mathrm{P}<0.01\right)$.

others also confirmed p38 MAPK involvement in protooncogene c-jun mRNA upregulation and protein expression (Feidantsis et al., 2012).

In this study, we found that the ANP, BNP, c-fos, and c-jun mRNA levels were lower in the TA treatment group than in the ISO group. In the ISO group, the expression of the apoptotic proteins had dramatically increased in the heart tissue of the mice. Compared to the ISO model group, the proportion of Bax/ Bcl-2 and caspase- 3 were dramatically decreased in the myocardium after TA group.

Recently, it has been suggested that TNF- $\alpha$ upregulates TLR4 expression by activating NF- $\mathrm{KB}$ (p65), leading to an upregulation of Bax/Bcl-2 and Caspase-3. These experimental results show that in the TA group, the apoptotic protein expressions [NF- $\mathrm{KB}$ (P65), TLR4, p38] had effectively resisted with ISO group. However, determining whether the NF- $\mathrm{KB}$ (P65)/TLR4 signaling pathway is involved in the protective effects of TA injection on cardiac hypertrophy will require further investigation.

\section{CONCLUSION}

Overall, the present results indicate that TA exerts significant cardioprotective effects in mice with ISO-induced cardiac fibrosis. This protection might beachieved by suppressing the increases in NF- $\mathrm{KB}$ (P65), TLR4, p38 expression. Therefore, TA significantly ameliorated ISO-induced MF, possibly through its ability to suppress the TLR4-mediated NF- $\kappa \mathrm{B}$ signaling pathway.

\section{DATA AVAILABILITY STATEMENT}

The raw data supporting the conclusions of this article will be made available by the authors, without undue reservation, to any qualified researcher.

\section{ETHICS STATEMENT}

The animal care and experimental protocols were verified by the Hebei University of Chinese Medicine Committee on Animal Care, and then fulfilled according to the ethical standards laid down in the 1964 Declaration of Helsinki and its later amendments.

\section{AUTHOR CONTRIBUTIONS}

YG, SS, and LC conceived the experiments. HD and XH collected the samples. DM, BZ, and XH conducted the experiments. DM, JZ, and LC wrote the manuscript. DM and XZ analyzed the results. All authors read and approved the final manuscript.

\section{FUNDING}

This work was supported by the Natural Science Fund of Education Department of Hebei Province (No. ZD2019006). 


\section{REFERENCES}

Avlas, O., Fallach, R., Shainberg, A., Porat, E., and Hochhauser, E. (2011). Toll-like receptor 4 stimulation initiates an inflammatory response that decreases cardiomyocyte contractility. Antioxid. Redox Sign. 15, 1895-1909. doi: 10.1089 /ars.2010.3728

Ayala, P., Montenegro, J., Vivar, R., Letelier, A., Urroz, P. A., Copaja, M., et al. (2012). Attenuation of endoplasmic reticulum stress using the chemical chaperone 4-phenylbutyric acid prevents cardiac fibrosis induced by isoproterenol. Exp. Mol. Pathol. 92, 97-104. doi: 10.1016/j.yexmp.2011.10.012

Boluyt, M. O., Long, X., Eschenhagen, T., Mende, U., Schmitz, W., Crow, M. T., et al. (1995). Isoproterenol infusion induces alterations in expression of hypertrophy-associated genes in rat heart. Am. J. Physiol. 269, 638-647. doi: 10.1152/ajpheart.1995.269.2.H638

Borges, J. C., Silva, J. A. Jr., Gomes, M. A., Lomez, E. S., Leite, K. M., Araujo, R. C., et al. (2003). Tonin in rat heart with experimental hypertrophy. Am. J. PhysiolHeart. C. 284, 2263-2268. doi: 10.1152/ajpheart.00416.2002

Chu, X., Guo, Y., Xu, B., Li, W., Lin, Y., Sun, X., et al. (2015). Effects of tannic acid, green tea and red wine on hERG channels expressed in HEK293 Cells. Plos. One 10, e0143797. doi: 10.1371/journal.pone.0143797

Chu, X., Wang, H., Jiang, Y. M., Zhang, Y. Y., Bao, Y. F., Zhang, X., et al. (2016). Ameliorative effects of tannic acid on carbon tetrachloride-induced liver fibrosis in vivo and in vitro. J. Pharmacol. Sci. 130, 15-23. doi: 10.1016/ j.jphs.2015.12.002

Cowling, R. T., Kupsky, D., Kahn, A. M., Daniels, L. B., and Greenberg, B. H. (2019). Mechanisms of cardiac collagen deposition in experimental models and human disease. Transl. Res. 209, 138-155. doi: 10.1016/j.trsl.2019.03004

De Chiara, G., Marcocci, M. E., Torcia, M., Lucibello, M., Rosini, P., Bonini, P., et al. (2006). Bcl-2 Phosphorylation by p38 MAPK: identification of target sites and biologic consequences. J. Biol. Chem. 281, 21353-21361. doi: 10.1074/ jbc.M511052200

Duygu, B., Poels, E. M., and da Costa Martins, P. A. (2013). Genetics and epigenetics of arrhythmia and heart failure. Front. Genet. 4, 219. doi: 10.3389/fgene.2013.00219

Eguchi, K., and Manabe, I. (2014). Toll-like receptor, lipotoxicity and chronic inflammation: the pathological link between obesity and cardiometabolic disease. J. Atheroscler. Thromb. 21, 629-639. doi: 10.5551/jat.22533

Elliott, P. M., Poloniecki, J., Dickie, S., Sharma, S., Monserrat, L., Varnava, A., et al. (2000). Sudden death in hypertrophic cardiomyopathy: identification of high risk patients. J. Am. Coll. Cardiol. 36, 2212-2218. doi: 10.1016/s0735-1097(00) 01003-2

Feidantsis, K., Portner, H. O., Markou, T., Lazou, A., and Michaelidis, B. (2012). Involvement of p38 MAPK in the induction of Hsp70 during acute thermal stress in red blood cells of the gilthead sea bream, Sparus aurata. J. Exp. Zool. Part A. 317, 303-310. doi: 10.1002/jez.1725

Freund, C., Schmidt-Ullrich, R., Baurand, A., Dunger, S., Schneider, W., Loser, P., et al. (2005). Requirement of nuclear factor-kappaB in angiotensin II-and isoproterenol-induced cardiac hypertrophy in vivo. Circulation 111, 23192325. doi: 10.1161/01.CIR.0000164237.58200.5A

Gali, H. U., Perchellet, E. M., Klish, D. S., Johnson, J. M., and Perchellet, J. P. (1992). Hydrolyzable tannins: potent inhibitors of hydroperoxide production and tumor promotion in mouse skin treated with 12-O-tetradecanoylphorbol13-acetate in vivo. Int. J. Gynecol. Cancer. 51, 425-432. doi: 10.1093/carcin/ 13.4.715

Gupta, S., Young, D., Maitra, R. K., Gupta, A., Popovic, Z. B., Yong, S. L., et al. (2008). Prevention of cardiac hypertrophy and heart failure by silencing of NFкB. J. Mol. Biol. 375, 637-649. doi: 10.1016/j.jmb.2007.10.006

Haslam, E., Lilley, T. H., Cai, Y., Martin, R., and Magnolato, D. (1989). Traditional herbal medicines-the role of polyphenols. Planta. Med. 55, 1-8. doi: 10.1055/s2006-961764

Henis, Y., Tagari, H., and Volcani, R. (1964). Effect of water extracts of carob pods, tannic acid, and their derivatives on the morphology and growth of microorganisms. Appl. Microbiol. 12, 204-209. doi: 10.1128/AEM.12.3.204209.1964

Hu, X., Wang, H., Lv, X., Chu, L., Liu, Z., Wei, X., et al. (2015). Cardioprotective effects of tannic acid on isoproterenol-induced myocardial injury in Rats: further insight into 'french paradox'. Phytother. Res 9, 1295-1303. doi: 10.1002/ ptr.5376
Li, Z., Tran, T. T., Ma, J. Y., O'Young, G., Kapoun, A. M., Chakravarty, S., et al. (2004). P38 alpha mitogen-activated protein kinase inhibition improves cardiac function and reduces myocardial damage in isoproterenol-induced acute myocardial injury in rats. J. Cardiovasc. Pharm. 44, 486-492. doi: 10.1677/jme.1.02005

Li, X., Zhang, Z. L., and Wang, H. F. (2017). Fusaric acid (FA) protects heart failure induced by isoproterenol (ISP) in mice through fibrosis prevention via TGF-beta1/SMADs and PI3K/AKT signaling pathways. Biomed. Pharmacother 93, 130-145. doi: 10.1016/j.biopha.2017.06.002

Liang, Y., Qiu, J., Gao, H. Q., and Li, B. Y. (2009). Protective effect of grape seed proanthocyanidins extracts on reperfusion arrhythmia in rabbits. J. Nutr. Sci. Vitaminol. 55, 223-230. doi: 10.3177/jnsv.55.223

Liu, M., Chen, J., Huang, Y., Ke, J., Li, L., Huang, D., et al. (2015). Triptolide alleviates isoprenaline-induced cardiac remodeling in rats via TGF-beta1/ Smad3 and p38 MAPK signaling pathway. Pharmazie 70, 244-250. doi: $10.1691 / \mathrm{ph} .2015 .4799$

O’Neill, L. A., Bryant, C. E., and Doyle, S. L. (2009). Therapeutic targeting of Tolllike receptors for infectious and inflammatory diseases and cancer. Pharmacol. Rev. 61, 177-197. doi: 10.1124/pr.109.001073

Oka, T., Akazawa, H., Naito, A. T., and Komuro, I. (2014). Angiogenesis and cardiac hypertrophy: maintenance of cardiac function and causative roles in heart failure. Circ. Res. 114, 565-571. doi: 10.1161/CIRCRESAHA.114.300507

Qiu, J., Grafe, M. R., Schmura, S. M., Glasgow, J. N., Kent, T. A., Rassin, D. K., et al. (2001). Differential NF-kappa B regulation of bcl-x gene expression in hippocampus and basal forebrain in response to hypoxia. J. Neurosci. Res. 64, 223-234. doi: 10.1002/jnr.1070

Reagan-Shaw, S., Nihal, M., and Ahmad, N. (2008). Dose translation from animal to human studies revisited. Faseb. J. 22, 659-661. doi: 10.1096/fj.07-9574LSF

Sanyal, R., Darroudi, F., Parzefall, W., Nagao, M., and Knasmuller, S. (1997). Inhibition of the genotoxic effects of heterocyclic amines in human derived hepatoma cells by dietary bioantimutagens. Mutagenesis 12, 297-303. doi: 10.1093/mutage/12.4.297

Sato, M., Maulik, G., Ray, P. S., Bagchi, D., and Das, D. K. (1999). Cardioprotective effects of grape seed proanthocyanidin against ischemic reperfusion injury. J. Mol. Cell. Cardiol. 31, 1289-1297. doi: 10.1006/jmcc.1999.0961

Shyu, K. G., Wang, B. W., Lin, C. M., and Chang, H. (2010). Cyclic stretch enhances the expression of toll-like receptor 4 gene in cultured cardiomyocytes via p38 MAP kinase and NF-kappaB pathway. J. Biomed. Sci. 17, 15. doi: 10.1186/1423-0127-17-15

Thiansilakul, Y., Benjakul, S., Grunwald, E. W., and Richards, M. P. (2012). Retardation of myoglobin and haemoglobin-mediated lipid oxidation in washed bighead carp by phenolic compounds. Food. Chem. 134, 789-796. doi: 10.1016/j.foodchem.2012.02.182

Wu, C., Yan, L., Depre, C., Dhar, S. K., Shen, Y. T., Sadoshima, J., et al. (2009). Cytochrome c oxidase III as a mechanism for apoptosis in heart failure following myocardial infarction. Am. J. Physiol-Cell. Ph. 297, 928-934. doi: 10.1152/ajpcell.00045.2009

Yin, F., Wang, Y. Y., Du, J. H., Li, C., Lu, Z. Z., Han, C., et al. (2006). Noncanonical cAMP pathway and p38 MAPK mediate beta2-adrenergic receptor-induced IL-6 production in neonatal mouse cardiac fibroblasts. J. Mol. Cell. Cardiol. 40, 384-393. doi: 10.1016/j.yjmcc.2005.12.005

Yin, Q., Lu, H., Bai, Y., Tian, A., Yang, Q., Wu, J., et al. (2015). A metabolite of Danshen formulae attenuates cardiac fibrosis induced by isoprenaline, via a NOX2/ROS/p38 pathway. Brit. J. Pharmacol. 172, 5573-5585. doi: 10.1111/ bph.13133

Yugarani, T., Tan, B. K., and Das, N. P. (1993). The effects of tannic acid on serum lipid parameters and tissue lipid peroxides in the spontaneously hypertensive and Wistar Kyoto rats. Planta. Med. 59, 28-31. doi: 10.1055/s-2006-959598

Zhang, W., Elimban, V., Nijjar, M. S., Gupta, S. K., and Dhalla, N. S. (2003). Role of mitogen-activated protein kinase in cardiac hypertrophy and heart failure. Exp. Clin. Cardiol. 8, 173-183. doi: 10.1007/978-3-540-29805-2_2439

Zhang, Y., Chu, X., Liu, L., Zhang, N., Guo, H., Yang, F., et al. (2016a). Tannic acid activates the Kv7.4 and Kv7.3/7.5 K $\mathrm{K}^{+}$channels expressed in HEK293 cells and reduces tension in the rat mesenteric arteries. J. Pharm. Pharmacol. 68, 494502. doi: $10.1111 /$ jphp. 12527

Zhang, Y., Xu, J., Long, Z., Wang, C., Wang, L., Sun, P., et al. (2016b). Hydrogen (H2) inhibits isoproterenol-induced cardiac hypertrophy via antioxidative pathways. Front. Pharmacol. 7, 392. doi: 10.3389/fphar.2016.00392 
Zhang, J., Cui, L., Han, X., Zhang, Y., Zhang, X., Chu, X., et al. (2017a). Protective effects of tannic acid on acute doxorubicin-induced cardiotoxicity: Involvement of suppression in oxidative stress, inflammation, and apoptosis. Biomed. Pharmacother. 93, 1253-1260. doi: 10.1016/j.biopha.2017.07.051

Zhang, J., Song, Q., Han, X., Zhang, Y., Zhang, Y., Zhang, X., et al. (2017b). Multitargeted protection of acetaminophen-induced hepatotoxicity in mice by tannic acid. Int. Immunopharmacol. 47, 95-105. doi: 10.1016/ j.intimp.2017.03.027

Zhao, G., Gao, H., Qiu, J., Lu, W., and Wei, X. (2010). The molecular mechanism of protective effects of grape seed proanthocyanidin extract on reperfusion arrhythmias in rats in vivo. Biol. Pharm. Bull. 33, 759-767. doi: 10.1248/ bpb.33.759

Zheng, Z., Chen, H., Xu, X., Li, C., and Gu, Q. (2007). Effects of angiotensinconverting enzyme inhibitors and beta-adrenergic blockers on retinal vascular endothelial growth factor expression in rat diabetic retinopathy. Exp. Eye. Res. 84, 745-752. doi: 10.1016/j.exer.2006.12.013
Zhu, F., Chu, X., Wang, H., Zhang, X., Zhang, Y., Liu, Z., et al. (2016). New findings on the effectsof tannic acid: inhibition of L-type calcium channels, calcium transient and contractility in rat ventricular myocytes. Phytother. Res. 30, 510-516. doi: $10.1002 /$ ptr.5558

Conflict of Interest: The authors declare that the research was conducted in the absence of any commercial or financial relationships that could be construed as a potential conflict of interest.

Copyright ( 2020 Ma, Zheng, Du, Han, Zhang, Zhang, Gao, Sun and Chu. This is an open-access article distributed under the terms of the Creative Commons Attribution License (CC BY). The use, distribution or reproduction in other forums is permitted, provided the original author(s) and the copyright owner(s) are credited and that the original publication in this journal is cited, in accordance with accepted academic practice. No use, distribution or reproduction is permitted which does not comply with these terms. 